\title{
PENGGUNAAN MODEL PEMBELAJAR MIND MAPPING TERHADAP PEMAHAMAN KONSEP MATEMATIKA SISWA KELAS VIII
}

\author{
Beni Junedi ${ }^{1}$,Tika Permata Sari ${ }^{2}$ \\ ${ }^{1}$ Program Studi Pendidikan Matematika STKIP Insan Madani Airmolek, Riau \\ ${ }^{2}$ Program Studi Pendidikan Matematika STKIP Insan Madani Airmolek, Riau \\ Email: beni_junedi@yahoo.com, Tieca1hati@yahoo.com
}

\begin{abstract}
This research is motivated by the understanding of the mathematical conceps graders VIII Public Junior High school 2 Rakit Kulim is still low. This study aims to determine students understanding of mathematical conscepts by using mind mapping learning model is better than the students understanding of mathematical concepts by using conventional learning class VIII Public Junior High School 2 Rakit Kulim. Kind of research is experimental research with a study that Randomized Control Group Only Design. Population in this study class VIII, a sample class VIII A and VIII B data analysis using test-t as hypothesis testing, the analysis results $t_{\text {hitung }}=4,363$ dan $t_{\text {tabel }}=2,01$, karena $t_{\text {hitung }}>t_{\text {tabel }}$ weconcluded that students understanding of mathematical concepts by using mind mapping learning model is better than the students understanding of mathematical concepts with the use of conventional learning in class VIII Public Junior High school 2 Rakit Kulim.
\end{abstract}

Keyword: Mind Mapping, Students Understanding of Mathematical Concepts

\begin{abstract}
Abstrak
Penelitian ini dilatarbelakangi oleh pemahaman konsep matematika siswa kelas VIII Sekolah Menengah Pertama Negeri 2 Rakit Kulim masih rendah. Penelitian ini bertujuan untuk mengetahui pemahaman konsep matematika siswa dengan penggunaan model pembelajaran mind mapping lebih baik daripada pemahaman konsep matematika siswa dengan penggunaan pembelajaran konvensional kelas VIII Sekolah Menengah Pertama Negeri 2 Rakit Kulim. Jenis penelitian yang digunakan adalah penelitian eksperimen dengan rancangan penelitian yaitu randomized control group only design. Populasi pada penelitian ini kelas VIII, yang menjadi sampel kelas VIII A dan VIII B Teknik analisis data menggunakan uji-t sebagai uji hipotesis, hasil analisis diperoleh $t_{\text {hitung }}=4,363$ dan $t_{\text {tabel }}=2,01$, karena $t_{\text {hitung }}>t_{\text {tabel }}$ diperoleh kesimpulan bahwa pemahaman konsep matematika siswa dengan menggunakan model pembelajaran mind mapping lebih baik daripada pemahaman konsep matematika siswa dengan penggunaan pembelajaran konvensional di kelas VIII Sekolah Menengah Pertama Negeri 2 Rakit Kulim.
\end{abstract}

Kata Kunci: Mind Mapping, Pemahaman konsep matematika siswa

\section{PENDAHULUAN}

Mata pelajaran matematika merupakan bagian dari pendidikan diberikan kepada peserta didik yang dimulai dari sekolah dasar untuk membekali peserta didik ke jenjang berikutnya. Matematika merupakan ilmu dasar yang mempunyai peranan penting dalam perkembangan ilmu pengetahuan dan teknologi, dan salah satu mata pelajaran yang dianggap sulit diantara mata pelajaran lainnya, dan guru harus mempunyai kemampuan dalam menggunakan model pembelajaran yang tepat dalam materi pembelajaran yang akan diajarkan.

Mengingat luasnya pembahasan tentang permasalahan maka peneliti membatasi masalah, yaitu pemahaman konsep matematika siswa masih rendah, dengan mengunakan pembelajaran mind mapping 
pemahaman konsep siswa masih rendah kelas VIII Sekolah Menengah Pertama Negeri 2 Rakit Kulim dapat diatasi.

Tujuan penelitian adalah untuk mengetahui pemahaman konsep matematika siswa dengan penggunaan model pembelajaran Mind Mapping lebih baik daripada pemahaman konsep matematika siswa dengan menggunakan pembelajaran konvensional kelas VIII Sekolah Menengah Pertama Negeri 2 Rakit Kulim.

Penelitian ini mengacu kepada rumusan masalah apakah pemahaman konsep matematika siswa dengan penggunaan model pembelajaran Mind Mapping lebih baik dari pada pemahaman konsep matematika siswa dengan pembelajaran konvensional kelas VIII Sekolah Menengah Pertama Negeri 2 Rakit Kulim

Dengan menggunakan model pembelajaran yang tepat maka pemahaman konsep matematika siswa akan lebih meningkat. Menurut hemat penulis model pembelajarn Mind Mapping mampu membuat suasana pembelajaran yang menarik, kreatif dan menyenang. Mind Mapping atau pemetaan pikiran merupakan cara kreatif bagi tiap pembelajaran untuk menghasilkan gagasan, mencatat apa yang dipelajari, atau merencanakan tugas baru. Sedangkan munurut Hernowo Mind Mapping merupakan cara yang sangat baik untuk menghasilkan dan menata gagasan sebelum mulai menulis.

\section{METODE PENELITIAN}

Jenis penelitian ini adalah penelitian eksperimen. Desain penelitian yang digunakan adalah True Experimental Design. Dalam penelitian ini, terdapat dua kelompok yaitu kelompok kelas eksperimen dan kelas kontrol. Pada kelas eksperimen siswa akan diberikan perlakuan yaitu model pembelajaran mind mapping dalam proses pembelajarannya, sedangkan pada kelompok kelas kontrol, siswa diberikan perlakuan yaitu berupa pembelajaran konvensional

Rancangan penelitian dalam penelitian ini adalah Randomized Control Group Only Design. Terlihat pada tabel berikut.

Tabel 1. Rancangan penelitian

\begin{tabular}{|c|c|c|c|}
\hline & Group & $\begin{array}{c}\text { Variabel } \\
\text { Terikat }\end{array}$ & Posttest \\
\hline $\mathrm{R}$ & Eksperimen & $\mathrm{X}$ & $Y_{2}$ \\
\hline $\mathrm{R}$ & Kontrol & - & $Y_{2}$ \\
\hline
\end{tabular}

Dalam penelitian ini sekelompok subjek yang diambil dari populasi tertentu dikelompokkan secara rambang menjadi dua kelompok, yaitu kelompok eksperimen dan kelompok kontrol. Kelompok eksperimen dikenai variabel perlakuan tertentu dalam jangka waktu tertentu, lalu kedua kelompok itu di kenai pengukuran yang sama. Perbedaan yang timbul dianggap bersumber pada variabel perlakuan. 
Instrumen penelitian yang digunakan berupa tes kemampuan pemahaman konsep matematika siswa. Tes kemampuan pemahaman konsep matematika ini berupa tes tertulis. Tes tertulis ini akan diberikan kepada siswa baik kelas eksperimen maupun kelas kontrol sebagai tes akhir (posttest) yaitu berupa tes uraian yang terdiri dari 5 butir soal. Sebelum instrumen penelitian digunakan untuk memperoleh data instrumen ini maka terlebih dahulu diuji cobakan pada kelas yang berbeda untuk mengetahui validitas, reliabilitas, taraf kesukaran dan daya pembeda soal guna membuktikan bahwa instrumen penelitian ini baik. Teknik analisis data dalam penelitian ini adalah uji t sebagai uji hipotesis, dengan uji prasyarat yaitu uji normalitas dan uji homogenitas.

\section{HASIL DAN PEMBAHASAN}

Dalam penelitian ini digunakan dua kelas sebagai sampel yang diambil secara acak, dimana sebelumnya telah diuji kehomogenannya antara satu kelas dengan kelas yang lainnya. Kedua kelas tersebut adalah kelas VIII A sebagai kelas eksprimen yang menggunakan model pembelajaran Mind Mapping dan kelas VIII B sebagai kelas kontrol yang menggunakan model pembelajaran konvensional yang masing-masing berjumlah 31 dan 30 orang. Data penelitian yang diskripsikan yaitu pemahaman konsep matematika siswa pada ranah menyajikan konsep dalam berbagai bentuk reprentasi matematis, menggunakan dan memanfaatkan serta memilih prosedur atau operasi tertentu, dan mengaplikasikan konsep atau algoritma pemecahan masalah.

Untuk menarik kesimpulan dari hasil penelitian yang dilakukan, maka dilakukan uji hipotesis atau uji-t secara statistik. Sebelum dilakukan uji-t terlebih dahulu dilakukan uji normalitas dan uji homogenitas.

\section{a. Uji Normalitas}

Tabel 2 Hasil Uji Normalitas Data

\begin{tabular}{|l|c|c|c|c|}
\hline \multicolumn{1}{|c|}{ Kelas } & $\mathbf{N}$ & $\boldsymbol{L}_{\boldsymbol{m a k s}}\left(\boldsymbol{L}_{\boldsymbol{m}}\right)$ & $\boldsymbol{L}_{\text {tabel }}$ & Keterangan \\
\hline Eksprimen & 31 & 0,149 & 0,159 & Normal \\
\hline Kontrol & 30 & 0,153 & 0,161 & Normal \\
\hline
\end{tabular}

Dari tabel 2 diatas terlihat bahwa pada kedua kelas $L_{m a k s}<L_{\text {tabel }}$ bearti kedua sampel terdistribusi normal.

\section{b. Uji Homogenitas}

Tabel 3 Hasil Analisis Homogenitas Kelas Sampel

\begin{tabular}{|l|c|c|c|c|c|}
\hline \multicolumn{1}{|c|}{ Kelas } & $\mathbf{N}$ & Varians $\left(\boldsymbol{S}^{\mathbf{2}}\right)$ & $\boldsymbol{F}_{\text {hitung }}$ & $\boldsymbol{F}_{\text {tabel }}$ & Keterangan \\
\hline Eksprimen & 31 & 6,620 & 4,363 & 2,00 & Homogen \\
\cline { 1 - 3 } Kontrol & 30 & 4,7 & & & \\
\hline
\end{tabular}


Dari tabel 3 terlihat bahwa $F_{\text {hitung }}<F_{\text {tabel }}$, artinya kedua kelas mempunyai varians yang homogen.

\section{c. Uji Hipotesis}

Tabel 4 Hasil Uji hipotesis

\begin{tabular}{|l|c|c|c|c|c|c|}
\hline \multicolumn{1}{|c|}{ Kelas } & $\mathbf{N}$ & $\begin{array}{c}\text { Rata-rata } \\
(\overline{\boldsymbol{X}})\end{array}$ & $\begin{array}{c}\text { Varians } \\
\left(\boldsymbol{S}^{\mathbf{2}}\right)\end{array}$ & $\begin{array}{c}\text { Simpangan } \\
\text { baku (S) }\end{array}$ & $\boldsymbol{t}_{\text {hitung }}$ & $\boldsymbol{t}_{\text {tabel }}$ \\
\cline { 1 - 5 } Eksprimen & 31 & 16,935 & 6,620 & 2,944 & \multirow{2}{*}{4,363} & \multirow{2}{*}{2,00} \\
\cline { 1 - 5 } Kontrol & 30 & 14,3 & 4,7 & 2,639 & & \\
\hline
\end{tabular}

Dari tabel 4 dapat dilihat bahwa harga $t_{\text {hitung }}$ adalah 4,363 dan harga $t_{\text {tabel }}$ pada taraf nyata 0,05 atau tingkat kepercayaan $95 \%$ dengan $\mathrm{dk}=59$ adalah $1-1 / 2 \alpha=2,00$. Ini jelas bahwa hipotesisi statistik $H_{O}: \overline{X_{1}}>\overline{X_{2}}$ diterima. Dengan kata lain pemahaman konsep matematis siswa dengan penggunaan model pembelajaran Mind Mapping lebih baik dari pada pemahaman konsep matematis siswa dengan penggunaan pembelajaran konvensional (biasa) di kelas VIII Sekolah Menengah Pertama Negeri 2 Rakit Kulim.

\section{KESIMPULAN}

Berdasarkan hasil penelitian yang dilaksanakan di Sekolah Menengah Pertama Negeri 2 Rakit Kulim kelas VIII tahun ajaran 2015/2016 pada pembelajaran matematika diperoleh data tes pemahaman konsep matematika siswa. Pada kelas eksperimen diproleh rata-rata skor 16,935 dan kelas kontrol 14,3. Sedangkan berdasarkan hasil perhitungan uji hipotesis yang menggunakan uji-t, diperoleh harga $t_{\text {hitung }}=2,731$ dan $t_{\text {tabel }}=2,064$. Karena $t_{\text {hitung }}>t_{\text {tabel }}$ maka $\mathrm{H}_{0}$ ditolak dan $\mathrm{H}_{\mathrm{a}}$ diterima. Diperoleh kesimpulannya bahwa, pemahaman konsep matematika siswa dengan penggunaan model pembelajaran mind mapping lebih baik daripada pemahaman konsep matematika siswa dengan penggunaan pembelajaran konvensional kelas VIII Sekolah Menengah Pertama Negeri 2 Rakit Kulim.

\section{DAFTAR PUSTAKA}

Hamzah, Ali dan Muhlisrarini. 2014. Perencana dan Strategi Pembelajaran Matematika. Jakarta: Raja Grafindo Persada.

Helmi. 2013. Micro Teacing Melatih Keterampilan Dasar Mengaja. Yogyakarta: Aswaja Pressindo.

Shoimin, Aris. 2014. 68 Model Pembelajaran Inovatif dalam Kurikulum 2013. Yogyakarta: KDT

Sirwardani. 2008. Analisis SI dan SKL Mata Pelajaran Matematika SMP/MTs untuk optimalisasi Tujan Mata Pelajaran Matematika. Yogyakarta: Pusat 